\title{
Intra-corporate plagiarism? Conceptualising antecedents and consequences of negatively
}

perceived mobility of ideas

Arp, Frithjof

Lemański, Michał K.

The University of Nottingham, Ningbo, China

Paper submitted for consideration in Journal of Global Mobility. Revised and resubmitted 28 July 2016. Readers are advised to check the publisher version before citing specific content or page numbers. The publisher version of this paper is available at http://doi.org/10.1108/JGM-05-2016-0020 and can be cited as:

Arp, F., \& Lemanski, M. (2016). Intra-corporate plagiarism? Conceptualising antecedents and consequences of negatively perceived mobility of ideas. Journal of Global Mobility, 4(3), 257-275

Intra-corporate plagiarism? Conceptualising antecedents and consequences of negatively perceived mobility of ideas

\begin{tabular}{|r|l|}
\hline Journal: & Journal of Global Mobility \\
\hline Manuscript ID & JGM-05-2016-0020.R2 \\
\hline Manuscript Type: & Research Paper \\
\hline Keywords: & $\begin{array}{l}\text { Knowledge management, Mobility of ideas, Directionality, Plagiarism, } \\
\text { Multinational corporations, International business, Human resource } \\
\text { management }\end{array}$ \\
\hline
\end{tabular}




\title{
Intra-corporate plagiarism? Conceptualising antecedents and consequences of negatively perceived mobility of ideas
}

\begin{abstract}
Purpose - We examine and reflect on the mobility of ideas between Multinational Corporation (MNC) headquarters and subsidiaries. Does it always represent (positively perceived) knowledge transfer or can it sometimes constitute (negatively perceived) intra-corporate plagiarism? What are the antecedents and consequences of negatively perceived mobility of ideas?

Design/methodology/approach - We conceptualise inter-unit knowledge transfer in MNCs without recognition of originators as an act of intra-corporate plagiarism. Our conceptualisation is informed by theoretical perspectives in the literature and indicative data emerging unexpectedly from a study designed to examine knowledge transfer in MNCs. These illustrate the concept, point to factors affecting the propensity to plagiarise, and provide preliminary insight on both negative and positive consequences. Aiming to build theory, we offer propositions for further research.

Findings - Our conceptualisation suggests that adopting units lose access to the original sources of ideas as plagiarism victims may establish defensive strategies. Originators of ideas may experience loss of trust, be unsupportive of implementation, and erect barriers to future mobility. There is risk of reputation loss and rejection of ideas and practices from other units. However, our conceptualisation also suggests that, ironically and counterintuitively, plagiarism may increase the mobility of ideas within MNCs.
\end{abstract}

Research limitations - We do not test hypotheses and make no claims from our data about statistical validity or prevalence of the phenomenon. As our emergent data are not longitudinal, and specific to human resource management practices, we cannot empirically establish all 
antecedents and consequences of intra-corporate plagiarism. Hence, our theorisations primarily rely on perspectives in the literature. The study merely offers the theoretical conceptualisation of the phenomenon and propositions for future research.

Practical implications - Drawing on theoretical perspectives in the literature at the country-level (ethnocentrism, dominance effects, legitimacy, capability) and organisation-level (not-invented-here syndrome, micro-politics), the study indicates consequences that MNCs may wish to consider in their knowledge management.

Originality/value - Our first contribution is the conceptualisation of inter-unit knowledge transfer in MNCs without recognition of originators as an act of intra-corporate plagiarism. Second, we point out that knowledge transfer directionality reported in other research may be based on intentional or unintentional misrepresentation. Third, we theorise intra-corporate plagiarism as potentially useful in mitigating ethnocentrism, country-of-origin dominance effects and perceptions about legitimacy and capability.

Paper type - Research paper

\section{Keywords}

Knowledge management, mobility of ideas, directionality, plagiarism, multinational corporations

\section{Acknowledgements}

The second author gratefully acknowledges suggestions and comments from Ingmar Bjorkman and Guenter K. Stahl on earlier versions of this manuscript, help with data collection from Sebastian Lobo and Yordan Todorov, and financial support through research grants of WU Vienna and Erste Bank. Erste Bank did not serve as a research site, and did not influence the research process in any way. 
"Picasso used to say: good artists follow, and great artists just steal. And we were never ashamed of stealing great ideas"

Steve Jobs

\section{INTRODUCTION}

Inter-unit mobility of ideas and practices is of high significance to multinational companies (MNC), since it enhances their performance and competitive advantage over national firms (Edwards \& Tempel, 2010; Holm \& Sharma, 2006). Ideas and practices are valuable resources that MNCs try to replicate and exploit throughout the whole organisation (Björkman \& Lervik, 2007; Szulanski, 1996). Extensive evidence has therefore been collected on how MNCs transfer innovative practices between countries (Dobosz-Bourne, 2006; Edwards \& Ferner, 2004; Mol \& Birkinshaw, 2010; Tempel, 2001; Thory, 2008). When different MNC units start to utilise new practices that have proved successful elsewhere, the competitive advantage of the whole company grows (von Krogh, Ichijo, \& Nonaka, 2000: 208).

This mobility of ideas and practices is also significant for individual subsidiary units. Subsidiaries may enhance their status within the larger MNC structure if they are recognised as sources of new and useful practices that can be transferred to other units (Ferner \& Varul, 2000). Entrepreneurial behaviour of subsidiaries, expressed through the contribution of new practices, can also result in increased attention and improved perceptions at headquarters (HQs) of the firm (Birkinshaw, Hood, \& Young, 2005). Practices from subsidiaries can help fine-tune central strategy, improve processes in other units, and help improve coordination across the MNC. International subsidiaries play a particularly important role. By enabling and strengthening knowledge transfer of locally 
developed ideas and practices, HQs enlarge the pool of available organisational solutions tried out and 'tested' in different socio-economic and cultural environments, and reduce the cost of learning in other international units receiving such 'ready-and-tested' solutions (Ambos, Ambos, \& Schlegelmilch, 2006; Birkinshaw, 2000; Chini, 2005).

However, do subsidiaries always receive acknowledgment, recognition and reward for their ideas? Indeed, does the mobility of ideas always represent (positively perceived) knowledge transfer? Or can there be (negatively perceived) elements of plagiarism? We conceptualise in this manuscript intra-corporate plagiarism as an act through which units within MNCs adopt and/or disseminate ideas and practices developed by other units, presenting themselves as originators. Instead of acknowledging, recognising and rewarding the sources of innovation, credit for new ideas and practices is given to the plagiarising units.

Our conceptualisation is more specific to organisational contexts than, but congruent with, generic definitions of plagiarism. Importantly, commonly used definitions of plagiarism also refer to 'ideas' rather than more material objects (e.g. 'texts'). The Oxford Dictionary (2016) defines plagiarism as "the practice of taking someone else's work or ideas and passing them off as one's own", while the Merriam-Webster Learner's Dictionary (2016) defines it as "the act of using another person's words or ideas without giving credit to that person". More detailed descriptions of 'idea theft' have also been offered for contexts such as education (Dee \& Jacob, 2010) and scholarship (Bartunek, 2012; Honig \& Bedi, 2012). Following Stinchcombe (1965), we acknowledge that MNC parent companies, and HQs as their decision-making apparatus, have a general legal claim on the assets, resources, income, and related rights of their subsidiaries. Yet individual subsidiary units, employees, and managers in subsidiaries are not necessarily obliged to 
proactively develop new ideas and practices for MNC-wide use. When they convey ideas and practices, they may therefore perform activities potentially not mandated by corporate legal acts. Continued mobility of ideas may thus depend on perceptions of fairness and recognition within MNCs. Employees and managers in units that originate innovative ideas and practices may seize to do so in the absence of acknowledgment, recognition and reward.

There are notable similarities but also important differences between organisational learning through mobility of ideas, and plagiarism. Knowledge transfer occurs in both instances, because ideas and practices developed in one unit are adopted by HQs, other subsidiaries, or even companywide. Yet, it is intuitively assumed that for (positively perceived) mobility of ideas, acknowledgement, recognition and reward is essential. Literature suggests potential recognition for initiative as one of the significant reasons for engaging in reverse diffusion of HRM practices (Edwards \& Ferner, 2004). Subsidiaries that originate new practices diffused within MNCs may enhance their status and claim on resources (Ferner \& Varul, 2000). Edwards and Tempel (Edwards \& Tempel, 2010: 272) extend this concept of enhanced status to other organisational levels and note that managers who act as originators of new practices to the MNC network may expect promotions or material rewards from HQs. In addition, employees and managers from other country units who adopt new practices that gained recognition in the MNC as 'best practice' may want to adopt them partly because failure to do so could lead to being perceived as lagging behind the corporate standards. Thus, acknowledgement, recognition and reward for innovative ideas and practices are relevant to all actors involved, at both organisational and individual level. If the mobility of ideas is perceived as (negative) plagiarism rather than (positive) knowledge transfer, this can potentially affect all MNC actors involved in the transfer. 
While inter-unit mobility of ideas and practices continues to receive significant attention of scholars (Chung, 2014; Edwards, Sanchez-Mangas, Bélanger, \& McDonnell, 2015; Ferner, Edwards, \& Tempel, 2012; Lemański, 2014), the dominant assumption in the literature is that knowledge transfer is always a positively perceived phenomenon (see e.g. Michailova \& Mustaffa, 2012). Potentially negative phenomena associated with knowledge transfer, such as perceptions of intra-corporate plagiarism remain underexplored in spite of their potential significance. Neither do we know about antecedents nor about consequences of intra-corporate plagiarism for subsequent mobility of ideas and practice sharing. This paper addresses this gap.

We do not question the positive effects of the mobility of ideas but provide a more complete view by offering theoretical insights and indicative evidence. Specifically, we draw on theoretical perspectives at the country- and organisation-level in the literature to conceptualise intra-corporate plagiarism, its antecedents and consequences. This conceptualisation helps explain the phenomenon of negative perceptions which we present in the subsequent sections. We offer preliminary propositions on antecedents and consequences of the phenomenon observed. Finally, we discuss implications of this preliminary study for scholarship and practice of knowledge management in MNCs, and reflect on its limitations.

\section{LITERATURE REVIEW}

In this section we review theoretical perspectives on the mobility of ideas and practices that have relevance to antecedents and consequences of intra-corporate plagiarism. 


\section{Country-level effects on the mobility of ideas}

Despite MNCs 'globalising' they still have a tendency to retain developmental and innovative activities in their parent-country (Tregaskis, Edwards, Edwards, Ferner, \& Marginson, 2010). National characteristics of MNC parent-countries and subsidiary host-countries at least partly explain challenges and barriers to the transfer of innovative ideas and practices from foreign subsidiaries (Edwards \& Ferner, 2004; Edwards \& Tempel, 2010). Country-of-origin effects influence MNCs' propensity to engage in the mobility of ideas (Edwards \& Ferner, 2004).

\section{Ethnocentrism}

Thory (2008) observed strong country-of-origin effects in the form of ethnocentrism in subsidiaries of French MNCs in Scotland. The subsidiaries found it difficult to transfer HRM practices such as management training, career management and 'pay-for-performance' - not only due to organisational differences between parent- and host-country units but also due to the desire of the MNCs to retain their 'French-ness' and a reluctance to adopt 'Anglo-Saxon practices'. French managers were unwilling to accept superior organisational processes, solely due to these being 'foreign'. Similarly, Tempel (2001) discusses attitudes of German managers towards British and 'Americanised' practices. Thus, ethnocentrism can be identified as one barrier to the mobility of ideas and practices. It remains to be further explored, however, whether it can also help explain intra-corporate plagiarism. Would some $\mathrm{MNCs}$, based on ethnocentrism, plagiarise ideas and practices rather than acknowledge, recognise and reward them if found useful? To what extent does ethnocentrism explain the rejection of useful ideas and practices rejected between MNC units? 


\section{Dominance}

The theory of dominance effects (Smith \& Meiksins, 1995) is very relevant to HRM ideas and practices. Pudelko and Harzing (2007), for example, report dominance as the most important explanation for the adoption of HRM practices. Their findings appear to suggest directionality of 'best practices' from US HQs to subsidiaries from a large-scale study of MNCs headquartered in the United States, Japan and Germany, as well as their respective subsidiaries in the two other respective countries. The theory of dominance effects also implies that MNC units will object to the adoption of practices from countries perceived as less developed. For example, Western Europe has achieved higher levels of economic development than Central and Eastern European Countries (CEECs), and practices used in Western European units can be perceived as one of the sources of this success. Dominance theory and the liability-of-origin faced by emerging market firms (Ramachandran \& Pant, 2010: 243) indicates that managers in Western European HQs and subsidiaries may perceive practices used in emerging market subsidiaries as less advanced. This is potentially significant for the mobility of ideas and practices within MNCs, given their increasing role in emerging markets. Although it has become apparent that emerging markets can be a source of new and valuable knowledge (Prahalad \& Krishnan, 2008), research dedicated to the mobility of ideas and practices from emerging market subsidiaries of developed market MNCs is limited.

\section{Legitimacy}

The legitimacy of knowledge transfers from subsidiaries is increased by HQ involvement (Birkinshaw, Hood, \& Jonsson, 1998; Ciabuschi, Forsgren, \& Martin, 2011). In addition, MNC strategy plays a role. For example, Whitley (1999: 240) notes that MNCs do not always want to encourage acquired subsidiaries in CEECs to become significant contributors to their international 
knowledge networks. Thus it is possible that knowledge diffusion from CEECs or other emerging market subsidiaries elsewhere is not expected or welcomed. Legitimacy issues at the country-level also occur because emerging markets are viewed as underdeveloped and subsidiaries in such host-countries perceived as having to 'catch up' with standards. For example, subsidiary HRM practices in CEECs are viewed as moving towards the standards of Western Europe and not the other way round (Scholz \& Boehm, 2008).

\section{Capability}

Capability-based barriers to the mobility of ideas appear when subsidiaries operating in emerging markets have less developed organisational systems and practices. This is often the case because they are younger, smaller, and serve less sophisticated customers than MNC units in more advanced economies. Subsidiary capabilities, and perceptions about these capabilities at HQ, depend on the local environment in which subsidiaries are embedded and from which they can learn (Ambos et al., 2006; Chini, 2005; Ferner \& Varul, 2000). Since this environment is less developed in emerging markets, and efforts of many organisations are focused on satisfying basic needs (Michailova, Heraty, \& Morley, 2009), the opportunity to originate ideas and practices that could subsequently be transferred to developed market units is limited. Further, as emerging market organisations typically try to emulate 'Western' standards (Michailova et al., 2009), Western organisations do not find many good opportunities to learn new ideas and practices. Some areas of organisational practices in CEECs, for example, especially those related to HRM, are underdeveloped for historical reasons (Horwitz, 2011). Inefficient use of human resources was a major weakness during the decades of the planned economy. Management education in CEECs has since boomed and management training is widely available (Kozminski \& Yip, 2000), yet 
MNCs and their subsidiaries in CEECs find it difficult to recruit managerial talent (Larcon, 1998). Illustrating what has become known as 'brain drain' through self-initiated expatriation (Cerdin \& Selmer, 2013; Silvanto \& Ryan, 2014), the most capable individuals often migrate to developed economies, sometimes within their MNC employers (Al Ariss \& Crowley-Henry, 2013; Ryan, Silvanto, \& Brown, 2013). These trends further reinforce perceptions about a lack of capability in CEEC subsidiaries to contribute useful ideas and HRM practices.

Overall, the literature's country-level concepts of ethnocentrism, dominance, legitimacy and capability are all perception-based, referring to different aspects of the same phenomenon. We theorise that intra-corporate plagiarism - inter-unit knowledge transfer in MNCs without recognition of originators - may counterbalance country-of-origin effects and perceptions about legitimacy and capability. When there is no acknowledgment, recognition and reward for the originators of knowledge, this may resolve problematic ethnocentrism and dominance effects, and perceptions of limited legitimacy or capability. Perhaps ironically and counterintuitively, intra-corporate plagiarism might therefore have a positive effect on the mobility of ideas.

\section{Organisation-level effects on the mobility of ideas}

The origination of ideas and innovative HRM practices can be viewed as an act of subsidiary entrepreneurship. It is an autonomous bottom-up process rather than a task mandated top-down by HQ directives (Gupta \& Govindarajan, 2000). HQs do not fully determine subsidiary acts (Ferner et al., 2012). HQs and other external actors may enhance or hinder subsidiary entrepreneurship but it is up to subsidiaries to take the initiative and respond to opportunities (Birkinshaw et al., 2005; Birkinshaw \& Lingblad, 2005). 


\section{Not invented here}

Factors hindering the mobility of ideas and innovative practices include the 'not-invented-here' syndrome (Katz \& Allen, 1982). Affliction with this syndrome renders MNC units unable to absorb outside practices, in particular when communication with other units is further challenged by distance and language differences. Even when there is openness towards innovation and entrepreneurship from other units, there may be concerns about specific effects of subsidiary initiatives. HQs may resist subsidiary initiatives as a threat to their 'corporate immune system' (Birkinshaw \& Ridderstråle, 1999) or their status within the corporation (Katz \& Allen, 1982). Conceivably, this 'not invented here' phenomenon might be moderated by knowledge transfer directionality and country-of-origin effects. 'Not invented here'-sentiments may be moderated when HQs are located in 'developing' economies and subsidiaries in 'advanced' economies. Generally, however, when ideas and practices are presented as HQs innovations, it increases their legitimacy (Ciabuschi et al., 2011), and the commitment to adoption by other units (Birkinshaw et al., 1998; Birkinshaw, 1998).

\section{Micro-politics}

Edwards and Tempel (2010) argue that the mobility of ideas and practices should be seen as an organisational politics phenomenon, since at least some subsidiaries engage in it to raise their status and claim on resources or to position themselves as good citizens within the MNC. Mobility of ideas and practices may induce the fear of a loss of power at HQs, since subsidiaries who serve as sources of new practices may demand acknowledgment, recognition and reward for their developmental efforts. In the eyes of its stakeholders, HQs may lose some of their legitimacy when 
peripheral units are developing organisational solutions that are accepted as superior and introduced companywide (Edwards \& Tempel, 2010).

Birkinshaw (Birkinshaw, 1998, 2000) supports this view and elaborates on 'empire-building' in subsidiaries who demonstrate initiative in order to enlarge their mandates. Further, adopting new ideas and innovative practices requires change and the need to adapt to a new situation. This may lead to resistance of other MNC units. This seems to be confirmed by the findings of Kossek (1989) who observed that HRM innovations are better accepted by those units in the organisation for which those innovations are not directly designed.

Bartlett and Ghoshal (1989) argue that HQs must coordinate knowledge transfer, since they are best equipped with resources and positioned in the organisation network to perform that job. In addition, subsidiaries generally perceive themselves to be dependent on HQs and tend to comply with their mandates (Kostova \& Roth, 2002). In these circumstances, intra-corporate plagiarism may seem a rational choice. First, it may be a remedy for the 'not-invented-here' syndrome. The misrepresentation of ideas and practices as originated at HQ may serve to enhance their legitimacy across the MNC. Second, it may avoid claims on corporate resources by subsidiaries that have originated ideas and practices for the MNC (Ferner \& Varul, 2000). By originating and transferring ideas and practices, a subsidiary may develop its mandate (Birkinshaw \& Lingblad, 2005; Birkinshaw, 1998), but HQs may wish to control subsidiary development by plagiarising.

Overall, it can be argued that the mobility of ideas affects power relations within MNCs. We theorise from the above literature that intra-corporate plagiarism leaves the originator's credit in the hands of HQs, and denies subsidiaries the ability to claim rewards for their work. By plagiarising, HQs eliminate subsidiary empire building (Birkinshaw et al., 1998) and control 
power relations within the MNC when, for example, the $\mathrm{HQ}$ wishes to favour one subsidiary over another.

\section{Research questions}

Some may simply wish to ask "How prevalent is intra-corporate plagiarism?" and attempt to answer this question through methods such as large-scale surveys. However, we are sceptical about evidence on intra-corporate plagiarism obtained through quantitative methods. First, what sample should be surveyed: Subsidiary or HQ employees? Second, even survey evidence triangulated between HQs and subsidiaries would unlikely be robust, as survey items using the negatively connoted term 'plagiarism' could prompt biased responses. Third, even dyadic respondent pairs surveyed with items avoiding the term 'plagiarism' may not be useful: what constitutes plagiarism to some might be perceived as mere 'inspiration' by others. Indeed, we theorise that these difficulties may have caused prior research to overlook that knowledge transfer directionality can be based on intentional or unintentional misrepresentation. In addition, we question the usefulness of examining the prevalence of intra-corporate plagiarism. Allocating blame or engaging in debates about fairness or unfairness within MNCs is not our intention.

In contrast, we are interested in qualitative aspects that can only emerge from volunteered and unprompted information. Our view is informed by examples of plagiarism that unexpectedly emerged in a study of knowledge transfer between MNC subsidiaries and their HQs. For the purpose of framing these emergent data, we articulate our broad questions as:

Research question 1: What are the antecedents of intra-corporate plagiarism?

Research question 2: What are the consequences of intra-corporate plagiarism?

Our methods for the initial exploration of these questions are described in the following section. 


\section{MethodS}

Our indicative data come from a larger study on the mobility of ideas and HRM practices in MNCs operating in Central and Eastern Europe. This is a region that, due to its complexity and diversity, offers potential for adding to our understanding of international mobility of practices and ideas, especially those related to the management of people (Horwitz, 2011; Meyer \& Peng, 2005). Given the concept-generating and theory-development objectives of the larger project, our initial sample selection was based on the logic of sampling for maximum variety (cf. Ghoshal \& Bartlett, 1988). Hence, our efforts were motivated by the hope that a sample diversified by industry, country of origin, as well as size and scope of operations, would allow us to identify different aspects of the mobility of ideas and HRM practices. We study largish MNCs since they are believed to have sufficiently developed practices and systems (Vokic Vidovic, M., 2008). During one interview a subsidiary manager reported alleged plagiarism of one of the practices he had developed. That discovery made us alert to such instances in subsequent interviews, and prompted us to review the already collected interview materials. We found indicative evidence for intra-corporate plagiarism in three out of 45 studied MNCs. These three instances are presented and discussed in the following sections. The phenomenon genuinely emerged from the data rather than having been prompted by specific interview questions or survey items, as mentioned above. This illustrates a typical feature of qualitative research methods (see e.g. Ghauri, 2004) in that we had to re-consult our data and then the literature to determine what had been published on the phenomenon observed. Because of the limited number of studies on the topic and the relative novelty of this research, we decided to examine the phenomenon further. The present study thus 
represents an exploratory design, an approach that has been used in studies on related topics (Edwards \& Ferner, 2004; Edwards \& Tempel, 2010; Thory, 2008).

\section{Informants}

At HQs we interviewed managers that supervise HRM of international operations, and in subsidiaries we interviewed managers in charge of local HRM and exposed to international inter-unit communication. Thus, the informants for the present manuscript are HR managers and the General Manager of a subsidiary that does not have a dedicated HR department.

\section{Data collection and analysis}

We had used semi-structured interviews during the original data collection. The key advantage of qualitative methods and semi-structured interviews in particular that is important for this study is that they allow 'how' and 'who'-type questions (Creswell, 2007). This helps "open the black box" of newly observed organisational phenomena (Doz, 2011). Because of the geographical dispersion of the companies approached, interviews were conducted by phone. This to some extent increased the distance to, and anonymity of, the respondents, which perhaps increased their inclination to mention sensitive issues. In an effort to avoid reliance on single respondents, we approached both HQs and subsidiaries and triangulated information from these sources with other data such as employee magazines and corporate presentations. Interviews lasted between 30 minutes and one hour. Companies were first contacted via email in which we presented ourselves and the project, and explained that the focus of the study was on the mobility of ideas and HRM practices. After this initial contact, the specific individual respondents advised by the MNCs were approached through further emails to arrange appointments for the planned interviews, advise on research ethics guidelines, and clarify confidentiality issues. 
Interviews were recorded and transcribed. Interviews conducted in languages other than English by one of the authors were translated by two bilingual research assistants who consulted on their understanding of the recordings with the principal investigator. We took notes during the process of contacting companies and respondents, and during the interviews. We first noted perceptions of plagiarism in instances where our respondents first hinted and subsequently told us about HQ managers 'copying' or 'stealing' ideas and HRM practices. The robustness of the theme in the larger research project and phenomenon of interest here was confirmed by a third research assistant who was given the respective interview transcripts and asked to categorise the roles played by HQs in each case of knowledge transfer. This categorisation confirmed our own when compared and we ultimately categorised three cases as illustrative acts of intra-corporate plagiarism. The examples have been renamed here but identified to the reviewers of this study and editors of this journal.

\section{FINDINGS}

The following examples do not represent intra-corporate plagiarism in all its potential variety but illustrate situations where the mobility of ideas within MNCs can be perceived negatively. Specifically, the flow of knowledge and ideas on innovative human resource management practices from subsidiaries to corporate HQs was perceived as plagiarism.

\section{Case 1: LICO}

LICO is an MNC manufacturing, assembling, selling and servicing industrial products. Following decades of family ownership, the company was listed on a stock exchange and employs over seven thousand employees in Europe (both East and West). The subsidiary examined here is located in a 
country larger but economically less developed than the MNC home country. It was initially established as a small representative office and now operates as a full sales subsidiary. Based on observations of the local labour market and his own experience, the country manager developed a remuneration system including a variable pay scheme. When he presented his ideas to the HQ for adoption in his own and other countries, they were not yet a practice in use in the subsidiary but merely a proposal. His suggestion was rejected as being incompatible with the corporation's global HR strategy. The manager explained:

I tried to implement a different motivation system. It was the motivation system for the sales representatives. I wanted that a variable part of the salary would depend on the profit they earn. So this means they get a certain percentage of the profit earned. I came up with this idea, but it was cancelled.

Soon after, a very similar remuneration system for sales representatives was introduced across the entire MNC. It was presented by the HQ manager who had been unsupportive of the original ideas presented by the subsidiary manager and included the variable pay scheme. The subsidiary manager reports:

Based on this idea the HR manager developed his own motivation system but still, it is better than the system that existed before.

The subsidiary manager further describes as a reward in itself the successful adoption of his original idea.

The reward for me would be that if I convince them [the HQ] to change the salary system for example my people will work better, will be more efficient. So this is the reward for me...that I have a more motivated team. But a reward from the HQs... it doesn't exist.

Two managers at HQ that we interviewed (Sales and HR) did not report any ideas or practices adopted from that subsidiary. Although we specifically asked about new practices or ideas coming from CEEC subsidiaries, and HRM practices that may have been implemented as a result of ideas presented by subsidiary managers, we were told that practices generally originate at HQ. Indeed, 
the HQs managers openly stated that no practices are ever transferred from their emerging market subsidiaries. They described exclusively unidirectional transfers of practices from the company's HQ for implementation in the subsidiaries. Located in a highly developed country, HQ managers in this MNC view their practices as superior to those in less advanced economies and emerging markets such as CEECs in particular.

\section{Case 2. FINCO}

FINCO is a European MNC offering a full portfolio of financial products and services. Publicly traded, the corporation was established through a merger of several financial institutions, has assets of several hundred billion Euro, and employs more than a hundred thousand. Its subsidiary analysed here is located in a smaller country but economically at a similar level to the country of the HQs. The subsidiary was established in the 1990s, also as a result of a series of mergers. It became a subsidiary of FINCO only recently and runs multiple operations as a regional centre. In this regional role, it is in charge of supervising about thirty percent of the entire workforce in multiple countries.

Our data indicate that the HQ plagiarised two subsidiary HRM practices: a student internship program, and an elaborate employee welcome day initiative. The subsidiary has had a tradition of student internships and apprenticeships, and that practice has been systematically institutionalised. In addition, the subsidiary developed a detailed 'Welcome Day' programme dedicated to the induction of new employees. The motivation to develop systematic and detailed programmes for both of these initiatives derives from this regional subsidiary's struggle with integration: It grew rapidly and dramatically in staff size through mergers and acquisitions after the collapse of the Soviet-bloc. Developing and implementing these initiatives in a systematic way was perhaps more 
urgent than at the HQ, which had a longer and slower history of integrating acquired and merged corporations.

During a visit to the subsidiary, HQs managers asked for details of reported subsidiary ideas and practices, without explanation for what purpose this information would be used. There was no follow-up by the HQ during subsequent communication with the subsidiary. Sometime later the HQ announced the MNC-wide introduction of a welcome day for new employees and a student internship program. Both initiatives closely resembled the two schemes developed in the subsidiary, and subsidiaries globally were asked to roll out the respective corporate practices. A subsidiary manager reports:

We have a welcoming day, for example, which is really a huge product now. I was thinking: "What the hell is going on there, why is it so super, great, because we did this for many years already. And we did this in a very big way, actually. [..] And then I recognised also that some people have "stolen" our material and suddenly it came up: "Look, the HQs is doing a new welcoming day." And I said, "Look, it's actually the same as our welcoming day. It actually follows the same times as our meeting schedule.

The subsidiary manager's reaction is of rather modest acceptance, and resembles the reaction in the other cases. It includes the implicit acceptance that, without the plagiarism, the mobility of ideas would perhaps have been less:

But then I thought, "Okay, if they like it so much, and someone else takes the crown for this, why bother? Now we all have the good chance to have a great welcoming day!"

However, some subsidiaries had already learned the respective practices directly from one another through direct communication. Most had modified the original ideas and practices to suit local circumstances or because they did not want to follow the originating subsidiary without adding their own 'national flavor'. This made the HQ-initiated global rollout more challenging. The HQ-plagiarised practices differed slightly from the original subsidiary practices and the other 
'national flavour' versions. Consequently, they were perceived as redundant by some subsidiary employees. A subsidiary manager elaborated on this issue:

Then they (i.e. HQs) come up with a great thing which we all should implement in the way they want to have it. They wanted to force us to give their idea to everyone and then you can of course understand that some countries started to say: "No, ours is better than this." And then it really depends on the managers, (...) and also on your way of dealing with this conflict. We take it as a war, "No, we will never do it," or you say, "Yeah, but why can't we do it like this?

This finding can be interpreted as initial evidence for one of our theorisations from the review of literature. Inter-unit knowledge transfer in MNCs without recognition of originators may counterbalance country-of-origin effects and inter-unit perceptions about legitimacy and capability. When there is no acknowledgment, recognition and reward for the originators of knowledge, HQs may be able to resolve problematic ethnocentrism effects, and the lack of perceived or actual legitimacy and capability.

\section{Case 3. APPLICO}

APPLICO is a global MNC operating in various industries. It is family owned, employs 33 thousand employees and its turnover exceeds 7.5 billion Euro. The division analysed here manufactures home appliances, was established in 1949 and operates production and sales facilities in multiple locations around the world. The subsidiary that served as our primary focal research site is located in a country both smaller and economically less developed than the MNC parent-country. The subsidiary started in 2000 as a greenfield investment and currently runs a full range of operations including manufacturing and sales. Its size, in terms of staff headcount, is about the same as the MNCs parent-country operations.

The manufacturing plant manager in that subsidiary had developed a systematic and standardised way of identifying, targeting, approaching and introducing new employees to the company, and 
presented this new practice to a regional HQ representative visiting the plant. However, the HQs manager seemed sceptical and actively discouraged the use of that practice. Nevertheless, the subsidiary manager believed that the practice he had developed was valid and beneficial to the company. On the occasion of a subsequent visit to the HQs he shared his innovative idea with a HQs manager of a higher rank than the person he talked to before. He reports:

I was astonished to hear from that guy: "Oh, that is a great idea, but Mr. X [the HQ manager he had previously talked to] is already implementing that here".

Learning that the manager who had criticised the innovate HRM practice originated at the subsidiary level now implemented the same practice at HQ does not appear to demotivate our interviewee. Indeed, in an emailed follow-up he responded in ways that indicate acceptance. Once again, this includes the implicit acceptance that, without the plagiarism, the mobility of ideas would have been less. An overview of our cases and instances of plagiarism is presented in the following table.

-- Insert table 1 about here -

\section{DISCUSSION}

In this section we examine our findings in light of the theorisations we derived from our literature review. In order to build theory, we offer preliminary propositions on antecedents and consequences of the phenomenon observed. In all three cases from which the phenomenon emerged, ideas and HRM practices that were originated in subsidiaries were implemented across the MNC's home country operations and other units. We conceptualise this mobility of ideas as intra-corporate plagiarism but propose that it occurs for understandable reasons, as commonalities go further: (a) In Cases 1 and 3, subsidiaries pro-actively and explicitly offered their innovative 
ideas and HRM practices to HQs while in Case 2, HQ managers were advised on the practices from regular reporting activities. (b) The ideas and HRM practices were implemented by HQs within a relatively short time after knowledge transfer took place. (c) In all three cases, the originating subsidiaries are located in countries 'less developed' than the HQ parent-country, with poor reputations for innovation. (d) Neither the originating individuals nor the subsidiaries were acknowledged, recognised or rewarded for their effort. In one of the cases they were even explicitly discouraged to continue the practice or share their ideas with other units. (e) In all three cases, the originators of the ideas and HRM practices explicitly describe this mobility of ideas as 'unauthorised copying' or 'stealing' i.e. plagiarism. At the same time, however, the affected managers accept that the outcomes of this plagiarism are broadly positive for the MNC and its subsidiaries. This includes the implicit acceptance that, without the plagiarism, the mobility of ideas would have been less.

\section{Country-level effects on the mobility of ideas}

We propose that our theorisations from the review of literature are corroborated by this initial evidence: Ironically and counterintuitively, intra-corporate plagiarism may have positive effects on the mobility of ideas. Without this misrepresentation of ideas and HRM practices as HQ-originated, their mobility across the entire MNC network may be limited by country-of-origin effects and perceptions about legitimacy and capability. The absence of acknowledgment, recognition and reward for the true originators of knowledge may help resolve problematic ethnocentrism and dominance effects. Innovative ideas and HRM practices originated by emerging market subsidiaries face significant hurdles in gaining acceptance at HQ or in other countries unless portrayed as HQ-originated i.e. plagiarised. Through this form of plagiarism, HQs fulfil their role of allocating corporate resources for the benefit of the entire MNC. 
More specifically, we analyse the phenomenon in light of the theoretical perspectives found in the literature. First, dominance effects (Smith \& Meiksins, 1995) influence our cases. In Case 1, HQs managers even stated openly that no ideas and HRM practices are ever transferred from emerging market subsidiaries to other units including the HQ. Intra-corporate plagiarism occurred to portray ideas and HRM practices as HQ-originated. Unsurprisingly, none of our HQ interviewees volunteered to admit plagiarism of subsidiary ideas. Indeed, rather than acknowledging the source of ideas, HQ managers may unintentionally attribute any valuable innovation to the headquarters' superior creative environment.

With this finding we make a separate contribution to theory. The finding is congruent with, but extends, other research (e.g. Pudelko \& Harzing, 2007) that appears to suggest unidirectional mobility of ideas. We suggest that research-identifiable directionality of innovative ideas and practices may not in fact exist. Instead, the directionality reported in other research may be based on the misrepresentation of innovative ideas and HRM practices originating in HQs. We suggest the contrarian theory that, in reality, the mobility of ideas and practices is always omnidirectional. Good ideas will be adopted, bad ones rejected. The location where they have originated and their purported directionality can be the subject of intentional and unintentional misrepresentation.

We identify intra-corporate plagiarism as the mechanism that helps such misrepresentation. It can also help overcome country-level perceptions about the country-of-origin. When there is a discrepancy between perceptions about the country-of-origin and the innovation value of an idea or practice, plagiarism may occur. Therefore one would expect that when such discrepancies are large, intra-corporate plagiarism is more likely to occur. We offer the following initial propositions for future hypothesis-testing. 
Proposition 1a: A large discrepancy between the innovation value of an idea and perceptions about the idea's country-of-origin reduces its mobility.

Proposition 1b: A large discrepancy between the innovation value of an idea and perceptions about the idea's country-of-origin increases the propensity of MNC HQs to engage in intra-corporate plagiarism

We further suggest that the effect of large discrepancies applies to both HQ and subsidiary managers. This is based on our observation that subsidiary managers, even when emotionally outraged about intra-corporate plagiarism, accept it as the mechanism for the mobility of their ideas. We propose:

Proposition 1c: Intra-corporate plagiarism to increase the mobility of innovative ideas finds acceptance even from the originators of the plagiarised ideas.

\section{Organisation-level effects on the mobility of ideas}

\section{Not invented here}

Our preliminary findings are consistent with literature on the 'not-invented-here' syndrome (Katz \& Allen, 1982), and observations that ideas and practices presented as HQ-originated increases their legitimacy (Ciabuschi et al., 2011) and commitment to absorption by other units (Birkinshaw et al., 1998; Birkinshaw, 1998). Even when there is openness towards subsidiary innovation and entrepreneurship, there may be concerns about specific effects of subsidiary initiatives. In our cases, data suggest that HQs resisted subsidiary initiatives as a threat to their 'corporate immune system' or their status within the corporation. In Case 2, this led to modifications of the original HRM practice, which subsequently made MNC-wide implementation more difficult. Arguably, plagiarism in Case 2 at an earlier stage and earlier portrayal of the ideas and practices as HQ-innovations may have increased their legitimacy (Ciabuschi et al., 2011) and commitment to absorption by other units (Birkinshaw et al., 1998; Birkinshaw, 1998). We therefore propose that:

Proposition 2a: Intra-corporate plagiarism can mitigate obstacles to the mobility of ideas when these obstacles are due to their 'reverse' nature (i.e. the directionality from subsidiary to HQs). 


\section{Micro-politics}

Nevertheless, intra-corporate plagiarism negatively affects subsidiaries since without acknowledgment, recognition and reward they are not able to capitalise on their innovation, claim more resources or expand their mandates. Hence, subsidiaries may modify future knowledge-transfer to reduce the possibility of plagiarism. By presenting their ideas and HRM practices in other forums, e.g. during public gatherings of subsidiary managers rather than individual meetings with single HQ managers, subsidiaries can make their contribution undeniable. Therefore we suggest:

Proposition 3a: Instances of intra-corporate plagiarism will alter subsequent channels for the mobility of ideas

Our data further suggests that HQ managers defend their position in the organisation when innovation originates in subsidiaries perceived as challenging the power position of HQs. In Case 2 , the subsidiary that originated the plagiarised practices is older than the parent country and is located in an advanced economy. HQs may perceive such subsidiaries as potential threat to their authority. We therefore propose:

Proposition 3b: In order to maintain positions of power, HQs will plagiarise ideas and HRM practices even when they originate in subsidiaries perceived as located in advanced economies and recognized as credible innovators.

On the other hand, HQs are easily able to plagiarise from units that are not able or willing to speak out against HQs' power. This includes young and small subsidiaries and isolated units that do not have much contact to other subsidiaries. Such subsidiaries perceive themselves as dependent on, and will tend to comply with, mandates coming from the parent (Kostova \& Roth, 2002). Our Cases 1 and 3 illustrate this. The LICO subsidiary in a CEEC was only a small representative office at the time when the idea was plagiarised, and completely dependent on the parent company 
on all resources. The APPLICO subsidiary was a newly established facility dependent on the parent on technology and financing. Our most obvious proposition therefore is:

Proposition 3c: Relatively low power of subsidiaries increases the propensity of HQs to plagiarise their ideas and practices.

\section{IMPLICATIONS}

Our study suggests that intra-corporate plagiarism, ironically and counterintuitively, assists the mobility of ideas within MNCs. Although we found this phenomenon in only three cases of a 45 company study, managerial attention should be paid to the propensity for, and consequences of, intra-corporate plagiarism. We make no claims from our sample about statistical validity or prevalence of the phenomenon. It can therefore only be speculated, for example, that intra-corporate plagiarism might be more prevalent for ideas in e.g. marketing or technical fields than for the HRM practices that we research. Nevertheless, its existence may signal problems with micro-politics, not-invented-here syndrome, and ethnocentrism within MNCs. At the same time, these problems may give HQs understandable reason to engage in intra-corporate plagiarism. Managers might want to assess and reflect on the prevalence and consequences of this phenomenon in their organisations. An overview of possible consequences of intra-corporate plagiarism is presented in the following table.

-- Insert table 2 about here -

\section{LIMITATIONS AND SUGGESTIONS FOR FUTURE RESEARCH}

Our research, inevitably, has significant limitations that lead us to suggestions for future research. First, our conceptualisations should be viewed only as a basis for further study. They are informed 
by theoretical perspectives in the literature, supported only by indicative data that emerged from a study designed for other research questions. The data were re-examined after discovery of the phenomenon of interest in this manuscript. Hence, our indicative data were not originally collected for the purpose of examining the specific phenomenon we discuss in the present manuscript. Instead, they result from a more general study on the mobility of ideas and HRM practices in MNCs.

Second, we were only able to report instances of intra-corporate plagiarism based on self-reporting by our interviewees and limited triangulation from employee magazines and corporate presentations. Research on controversial topics such as perceptions of plagiarism will always be limited by its dependence on respondents' memories and their readiness to honestly answer potentially sensitive interview or survey questions. However, additional sources of information such as company publications from a larger number of MNC units and further methods of triangulating information through e.g. independent third parties would be desirable. In consequence, our research does not make any claims about the prevalence of intra-corporate plagiarism. Indeed, entirely different methods would be needed to quantify such measures.

This leads us to the issue of definitions: It is difficult to define a clear distinction between plagiarism and re-invention. Both are perception-based and objective definitions would be required before further research could usefully be conducted. Future research should also clarify consequences of sustained intra-corporate plagiarism, ideally through longitudinal studies. Such an approach may be able to uncover how employees and managers perceive intent. For example, the HQ manager in our Case 3 appeared to act deliberately and strategically - with intent - when 'stealing' the subsidiary's HRM practice. Does this have an effect on how intra-corporate 
plagiarism is perceived? Future research should therefore compare intra-corporate plagiarism as deliberate, purposeful acts versus non-deliberate 'copy-cat' behaviour. Do intentional and unintentional behaviours have different consequences? It would also be interesting to compare intra-corporate plagiarism of explicit knowledge (such as technological innovations) versus more tacit knowledge (such as HRM practices that require a lot of experience). Such studies could shed more light on contextual variables, which in our paper are limited to the country-of-origin.

Finally, since we based our conceptualisation on theoretical approaches already widely used in research on the mobility of ideas, future research should examine intra-corporate plagiarism from new theoretical angles. For example, comparative studies of collectivistic versus individualistic cultures could shed more light on e.g. allegations and perceptions of plagiarism. Research questions could include whether the managers and employees of MNCs headquartered or operating in more collectivist societies perceive intra-corporate plagiarism differently from those in more individualistic societies. What are the differences when subsidiaries are located in individualistic and HQs in collectivistic societies versus subsidiaries in collectivistic and HQs in individualistic societies? Much research on the concept of intra-corporate plagiarism remains to be done.

\section{CONCLUSION}

This study contributes to a more holistic and balanced understanding of the intra-corporate mobility of ideas and practices by shedding some light on its potentially 'dark side'. Our study points to antecedents and consequences. Among its theoretical contributions is our suggestion that research-identifiable directionality may not in fact exist for innovative ideas and practices: Good 
ideas and practices are mobile and will be adopted regardless where they come from. Their purported directionality may be based on intentional or unintentional misrepresentation rather than facts.

\section{REFERENCES}

Al Ariss, A., \& Crowley-Henry, M. (2013). Self-initiated expatriation and migration in the management literature: Present theorizations and future research directions. Career Development International, 18(1), 78-96.

Ambos, T. C., Ambos, B., \& Schlegelmilch, B. B. (2006). Learning from foreign subsidiaries: An empirical investigation of HQs' benefits from reverse knowledge transfers. International Business Review, 15(3), 294-312.

Bartlett, C. A., \& Ghoshal, S. (1989). Managing across borders: The transnational solution. Boston, MA: Harvard Business School Press.

Bartunek, J. M. (2012). Introduction: Plagiarism in Submissions to the AOM Conference. Academy of Management Learning \& Education, 11(1), 99-100.

Birkinshaw, J. (1998). Corporate entrepreneurship in network organizations: How subsidiary initiative drives internal market efficiency. European Management Journal, 16(3), 355-364.

Birkinshaw, J. (2000). Entrepreneurship in the global firm. Thousand Oaks: Sage.

Birkinshaw, J., Hood, N., \& Jonsson, S. (1998). Building firm-specific advantages in multinational corporations: the role of subsidiary initiative. Strategic Management Journal, 19(3), 221242.

Birkinshaw, J., Hood, N., \& Young, S. (2005). Subsidiary entrepreneurship, internal and external competitive forces, and subsidiary performance. International Business Review, 14(2), 227248.

Birkinshaw, J., \& Lingblad, M. (2005). Intrafirm competition and charter evolution in the multibusiness firm. Organization Science, 16(6), 674-686.

Birkinshaw, J., \& Ridderstråle, J. (1999). Fighting the corporate immune system: a process study of subsidiary initiatives in multinational corporations. International Business Review, 8(2), 149-180.

Björkman, I., \& Lervik, J. E. (2007). Transferring HR practices within multinational corporations. Human Resources Management Journal, 14(7), 320-335.

Cerdin, J.-L., \& Selmer, J. (2013). Who is a self-initiated expatriate? Towards conceptual clarity of a common notion. The International Journal of Human Resource Management, 1-21.

Chini, T. C. (2005). Effective knowledge transfer in multinational corporations. Houndmills: 
Palgrave Macmillan.

Chung, L. (2014). Headquarters' Managerial Intentionality and Reverse Transfer of Practices. Management International Review, 54(2), 225-252.

Ciabuschi, F., Forsgren, M., \& Martin, O. M. (2011). Rationality vs ignorance: The role of MNE headquarters in subsidiaries' innovation processes. Journal of International Business Studies, 42(7), 958-970.

Creswell, J. W. (2007). Qualitative inquiry \& research design : choosing among five approaches (2nd ed.). Thousand Oaks, California: Sage Publications.

Dee, T. S., \& Jacob, B. A. (2010). Rational ignorance in education: A field experiment in student plagiarism (No. 15672). NBER Working Paper Series. Cambridge, MA, USA. Retrieved from http://www.nber.org/papers/w15672

Dobosz-Bourne, D. (2006). Reverse diffusion of quality: Evidence from General Motors UK and Poland. Journal for East European Management Studies, 11(3), 244-266.

Doz, Y. (2011). Qualitative research in international business. Journal of International Business Studies, 42(5), 582-590.

Edwards, T., \& Ferner, A. (2004). Multinationals, reverse diffusion and national business systems. Management International Review, 44(1), 49-79.

Edwards, T., Sanchez-Mangas, R., Bélanger, J., \& McDonnell, A. (2015). Why are some subsidiaries of multinationals the source of novel practices while others are not? National, corporate and functional influences. British Journal of Management, 26(2), 146-162.

Edwards, T., \& Tempel, A. (2010). Explaining variation in reverse diffusion of HR practices. Journal of World Business, 45(1), 19-28.

Ferner, A., Edwards, T., \& Tempel, A. (2012). Power, institutions and the cross-national transfer of employment practices in multinationals. Human Relations, 65(2), 163-187.

Ferner, A., \& Varul, M. (2000). "Vanguard" subsidiaries and the diffusion of new practices: A case study of German multinationals. British Journal of Industrial Relations, 38(1), 115-140.

Ghauri, P. (2004). Designing and conducting case studies in international business research. In R. Marschan-Piekkari \& C. Welch (Eds.), Handbook of qualitative research methods for international business (pp. 109-124). Cheltenham: Edward Elgar.

Ghoshal, S., \& Bartlett, C. A. (1988). Creation, adaptation and diffusion of innovations by subsidiaries or multinational corporations. Journal of International Business Studies, 19(3), $365-388$.

Gupta, A. K., \& Govindarajan, V. (2000). Knowledge flows within multinational corporations. Strategic Management Journal, 21(4), 273-496.

Holm, U., \& Sharma, D. D. (2006). Subsidiary marketing knowledge and strategic development of the multinational corporation. Journal of International Management, 12(1), 47-66.

Honig, B., \& Bedi, A. (2012). The Fox in the Hen House: A Critical Examination of Plagiarism 
Among Members of the Academy of Management. Academy of Management Learning \& Education, 11(1), 101-123.

Horwitz, F. (2011). Future HRM challenges for multinational firms in Eastern and Central Europe. Human Resource Management Journal, 21(4), 432-443.

Katz, R., \& Allen, T. J. (1982). Investigating the Not Invented Here (NIH) syndrome: A look at the performance, tenure, and communication patterns of $50 \mathrm{R} \& \mathrm{D}$ Project Groups. $R \& D$ Management, 12(1), 7-20.

Kossek, E. E. (1989). The acceptance of human resource innovation by multiple constituencies. Personnel Psychology, 42(2), 263-281.

Kostova, T., \& Roth, K. (2002). Adoption of an organizational practice by subsidiaries of multinational corporations: Institutional and relational effects. Academy of Management Journal, 45(1), 215-233.

Kozminski, A. K., \& Yip, G. S. (2000). Strategies for Central and Eastern Europe. Houndmills: Macmillan.

Larcon, J.-P. (1998). Entrepreneurship and economic transition in Central and Eastern Europe. Dordrecht: Kluwer Academic Publishers.

Lemański, M. K. (2014). Reverse Transfer of HRM Practices from Emerging Market Subsidiaries: Organizational and Country-Level Influences. In A. Verbeke, R. Van Tulder, \& S. Lundan (Eds.), Multinational Enterprises, Markets and Institutional Diversity (Progress in International Business Research, Volume 9) (Vol. 9).

Merriam-Webster: Plagiarism. (2016). Merriam-Webster Learner's Dictionary Online Edition. Retrieved from http://www.learnersdictionary.com/definition/plagiarism

Meyer, K. E., \& Peng, M. W. (2005). Probing theoretically into Central and Eastern Europe: transactions, resources, and institutions. Journal of International Business Studies, 36(6), $600-621$.

Michailova, S., Heraty, N., \& Morley, M. J. (2009). Managing. The case of central and eastern Europe. In M. J. Morley, N. Heraty, \& S. Michailova (Eds.), Managing human resources in Central and Eastern Europe. London: Routledge.

Michailova, S., \& Mustaffa, Z. (2012). Subsidiary knowledge flows in multinational corporations: Research accomplishments, gaps, and opportunities. Journal of World Business, 47(3), 383396.

Mol, M. J., \& Birkinshaw, J. (2010). Management innovation and the multinational corporation. In T. Devinney, T. Pedersen, \& L. Tihanyi (Eds.), The past, present and future of international business and managementAdvances in International Management (Vol. 23).

Oxford Dictionary: Plagiarism. (2016). Oxford Dictionary Online Edition. Retrieved from http://www.oxforddictionaries.com/us/definition/american_english/plagiarism

Prahalad, C. K., \& Krishnan, M. S. (2008). The new age of innovation. Driving co-created value through global networks. New York: McGraw-Hill. 
Pudelko, M., \& Harzing, A.-W. (2007). Country-of-origin, localization, or dominance effect? An empirical investigation of HRM practices in foreign subsidiaries. Human Resource Management, 46(4), 535-559.

Ramachandran, J., \& Pant, A. (2010). The liabilities of origin: An emerging economy perspective on the costs of doing business abroad. In A. Verbeke (Ed.), The past, present and future of international business and management. Advances in International Management. (Vol. 23). Emerald.

Ryan, J., Silvanto, S., \& Brown, H. T. (2013). The impact of experience-based MBA educational programs on international career mobility. Journal of Global Mobility: The Home of Expatriate Management Research, 1(1), 28-45. http://doi.org/10.1108/JGM-10-2012-0015

Scholz, C., \& Boehm, H. (2008). Human resource management in Europe. Comparative analysis and contextual understanding. London: Routledge.

Silvanto, S., \& Ryan, J. (2014). Relocation branding: a strategic framework for attracting talent from abroad: Journal of Global Mobility: The Home of Expatriate Management Research: Vol 2, No 1. Journal of Global Mobility, 2(1), 102-120.

Smith, C., \& Meiksins, P. (1995). System, society and dominance effects in cross-national organizational analysis. Work, Employment and Society, 9(2), 241-267.

Stinchcombe, A. L. (1965). Social structure and organizations. In J. G. March (Ed.), Handbook of Organizations (pp. 142-193). Chicago: Rand McNally \& Co.

Szulanski, G. (1996). Exploring Internal Stickiness: Impediments to the Transfer of Best Practice within the Firm. Strategic Management Journal , 17(Special winter issue), 27-43.

Tempel, A. (2001). The cross-national diffusion of human resource management practices in German and British multinational companies. Mering: Hampp.

Thory, K. (2008). The internationalisation of HRM through reverse transfer: two case studies of French multinationals in Scotland. Human Resource Management Journal, 18(1), 54-71.

Tregaskis, O., Edwards, T., Edwards, P., Ferner, A., \& Marginson, P. (2010). Transnational learning structures in multinational firms. Organizational context and national embeddedness. Human Relations, 63(4), 471-499.

Vokic Vidovic, M., N. P. (2008). HRM as a significant factor for achieving competitiveness through people: the Croatian case. International Advances in Economic Research., 4(3), 303315 .

von Krogh, G., Ichijo, K., \& Nonaka, I. (2000). Enabling knowledge creation. How to unlock the mystery of tacit knowledge and release the power of innovcation. Oxford: Oxford University Press.

Whitley, R. (1999). Divergent capitalisms. The social structuring and change of business systems. Oxford: Oxford University Press. 
Table 1 Summary of plagiarism cases

\begin{tabular}{|c|c|c|c|}
\hline Company & $\begin{array}{l}\text { HQ-subsidiary relationship } \\
\text { characteristics }\end{array}$ & Object of plagiarism & Outcome \\
\hline LICO & $\begin{array}{l}\text { Subsidiary located in a larger but } \\
\text { economically less developed country } \\
\text { than HQ } \\
\text { Subsidiary established in year } 2000 \text { as a } \\
\text { single representative, currently only sales } \\
\text { office of } 7 \text { people }\end{array}$ & $\begin{array}{l}\text { Incentive system for } \\
\text { sales force, including } \\
\text { pay-for-performance } \\
\text { profit sharing }\end{array}$ & $\begin{array}{l}\text { System introduced } \\
\text { companywide with } \\
\text { minor modifications }\end{array}$ \\
\hline FINCO & $\begin{array}{l}\text { Subsidiary located in smaller but } \\
\text { economically more developed country } \\
\text { than HQ } \\
\text { Subsidiary established in 1991, full range } \\
\text { of operations, regional centre, about } \\
30 \% \text { of total MNC workforce }\end{array}$ & $\begin{array}{l}\text { Welcome day; } \\
\text { Internship program }\end{array}$ & $\begin{array}{l}\text { Practice introduced } \\
\text { companywide with } \\
\text { modifications }\end{array}$ \\
\hline APPLICO & $\begin{array}{l}\text { Subsidiary located in a smaller and } \\
\text { economically less developed country } \\
\text { than HQs. } \\
\text { Subsidiary established in year } 2000, \text { full } \\
\text { range of operations, size about the same } \\
\text { as company home country operations. }\end{array}$ & $\begin{array}{l}\text { Introduction program } \\
\text { for new hires }\end{array}$ & $\begin{array}{l}\text { Practice introduced in } \\
\text { parent country } \\
\text { operations }\end{array}$ \\
\hline
\end{tabular}


Table 2 Potential consequences of plagiarism

\begin{tabular}{|l|l|l|}
\hline Affected parties & Positive consequences & Negative consequences \\
\hline MNC-wide & $\begin{array}{l}\text { Assists the mobility of ideas. Valuable } \\
\text { knowledge diffused. No allocation of new } \\
\text { resources required / no price paid for } \\
\text { obtaining new knowledge. May assist to } \\
\text { overcome country-level perceptions } \\
\text { about the country-of-origin }\end{array}$ & $\begin{array}{l}\text { Late stage intra-corporate plagiarism of innovative } \\
\text { ideas may hinder efficient absorption across units. } \\
\text { Adopting units have no access to the original source } \\
\text { of knowledge. Subsidiaries that are the victims of } \\
\text { plagiarism may establish defence strategies and alter } \\
\text { the channels for subsequent mobility of their ideas. }\end{array}$ \\
\hline HQs & $\begin{array}{l}\text { Assists the mobility of ideas. New ideas } \\
\text { and practices gained. No loss of power } \\
\text { and status. No allocation of new } \\
\text { resources to subsidiaries required. }\end{array}$ & $\begin{array}{l}\text { No support from originator for implementation. Loss } \\
\text { of subsidiary trust. Risk of reputation loss and } \\
\text { possible defensive strategies of subsidiaries. }\end{array}$ \\
\hline Subsidiaries & $\begin{array}{l}\text { Value of originated ideas confirmed. } \\
\text { Increased self-esteem. Benefits from } \\
\text { ideas albeit without the } \\
\text { acknowledgement, recognition and }\end{array}$ & $\begin{array}{l}\text { Loss of sources of power. Emotionally hurt } \\
\text { relationship with HQs. Need to establish self-defence } \\
\text { strategies. }\end{array}$ \\
\hline
\end{tabular}

